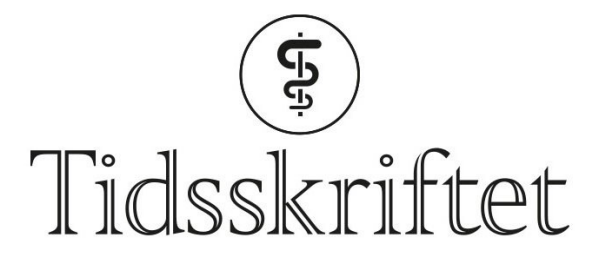

DEN NORSKE LEGEFORENING

\title{
De synkende hjerters sang
}

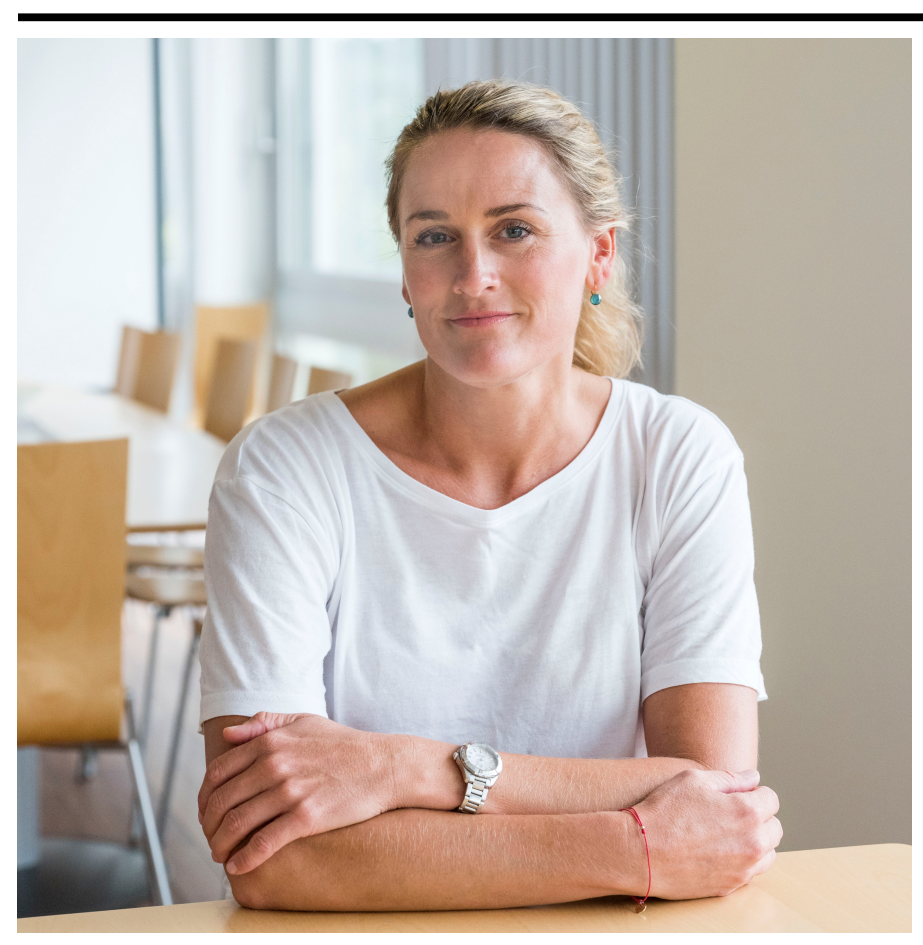

INTERVJU

RUNE SKOGHEIM

E-post: runeskogheim@hotmail.com

På mange pasientlister dukker det daglig opp gjengangere som kan åpne et dypt sug av frustrasjon i bunnen av enhver legesjel. Følelsen er gjerne gjensidig. Aase Aamland kjente suget tidlig, men gikk det i møte.

Jeg husker jeg satt som turnuslege på Lesja i Gudbrandsdalen og følte meg veldig alene, frustrert og ukomfortabel med disse pasientene. De her hadde jeg jo ikke hatt noe om på skolen, og ikke hadde jeg sett noe særlig til dem i løpet av sykehusåret heller, forteller hun.

«De». «MUPSene». Det fryktinngytende navnet på mørke pasientkrefter som tilsynelatende velter ut av jordens indre for å sige som en viskøs og energislukende masse over legelandskapet. De har Medisinsk Uforklarte Plager og Symptomer, eller «Medically Unexplained Physical Symptoms» (MUPS). Og de må tåle skylden for at et utall leger som har gledet seg til å bade i egen fortreffelighet, finner seg selv gispende i egen utilstrekkelighet.

- Og det er det ikke alle som takler like bra. En ikke uvanlig strategi er å «blame the victim», sier Aase Aamland lurt. 


\section{Som å komme hjem}

Sørlandsjenta ville egentlig ta videregående skole i utlandet og hadde etter hvert stilt kompasskursen mot Botswana. Hun havnet på Svalbard. I avslagsbrevet fra United World College fikk den reiselystne eleven tips om at skolen der oppe i det eksotiske Arktis årlig tok inn noen elever fra fastlandet.

\section{Aase Aamland}

Født 7. februar 1976

- Cand.med. Universitetet i Bergen 2002

- Allmennlege ved Vennesla legesenter siden 2005

- Spesialist i allmennmedisin siden 2012

- Legekyndig medlem i Kontrollkommisjonen i Vest-Agder 2006-13

- Ph.d. fra Universitetet i Bergen 2015 med avhandlingen Medisinsk uforklarte plager og symptomer og sykefravcer-allmennlegens rolle

- Seniorforsker ved Allmennmedisinsk forskningsenhet i Bergen

- Leder av Norsk forening for allmennmedisins referansegruppe for MUPS

- Nestleder iAllmennmedisinsk forskningsutvalg

- På den skolen var det ikke så mange valgmuligheter, så jeg ble rett og slett nødt til å ta realfag. Det var vel aldri helt med i min beregning, men plutselig hadde jeg det som trengtes for å studere medisin. Så jeg var en av de nerdene som begynte rett etter videregående.

- Jaså, du er av den sorten?

- Ja, vi som kom rett fra gymnaset følte oss litt sett ned på av de eldre studentene i Bergen som hadde gjort masse andre ting først.

-Kjipt?

- Tja, jeg tror vel egentlig vi taklet det veldig fint.

- Så hvordan trivdes du?

- Jeg trivdes ikke så veldig godt på studiet i starten, rent faglig. Det var mye tungt og tørt stoff. Men heldigvis fikk jeg et års utveksling til Berlin på preklinikken, da ble ting mer spennende igjen. Og det tok ikke lang tid før jeg skjønte at jeg kom til å like meg best i allmennmedisinen, forklarer Aamland.

Hun ville møte folk der ute, bli kjent med dem, hjelpe dem, følge dem opp. Når i tillegg foreleserne på allmennmedisinterminen viste seg som ualminnelig sympatiske og interesserte mennesker som endelig så studentene, var hun solgt.

- Det var som å komme hjem.

\section{De tre store hjertesynkerne}

Senere, som fastlege i Vennesla, hadde gleden over å komme hjem faglig begynt å blande seg med en snikende uro. Hver dag møtte hun pasienter hun ikke kunne hjelpe. Det var langt mellom de skyhøye TSH-verdiene, Mcburneys tegn og ST-elevasjonene. Folk hadde det vondt og vanskelig, og det trange kontoret besto så altfor ofte av to mennesker som ikke visste hvorfor.

- Etter hvert skjønte jeg at dersom jeg skulle klare å trives og vokse videre i dette faget, hadde det vært utrolig gøy å mestre disse situasjonene litt bedre. Både for pasientene og for 
min egen del. De kalles jo gjerne «heart-sink patients» på grunn av følelsen de gir legene. Når man ser et navn, umiddelbart tenker «Å nei...», og kjenner hjertet synke i kroppen før man går for å rope dem opp.

Dermed satte hun kursen mot kunnskapskilden for å vaske den mørke masken av det fremmede og vanskelige. Hun begynte å forske.

- Så hva er egentlig MUPS?

- Helt kort dreier det seg jo egentlig om subjektive symptomer uten objektive funn tilstander karakterisert av langvarige, plagsomme og funksjonsnedsettende symptomer.

- Som legen ikke vet hva er.

- Nettopp.

- Hvilke konkrete diagnoser snakker vi om da?

- Fibromyalgi, kronisk utmattelsessyndrom og irritabel tarm er vel de tre store det finnes mest forskning på. Men det finnes veldig mange andre plager uten kjent forklaring.

- Men hva med medikalisering av normale plager? Står ikke selve MUPS-begrepet i fare for å inkludere for mye av livet som sykdom?

- Jeg er veldig opptatt av at medisinsk uforklarte plager og symptomer ikke inkluderer hverdagslige, banale og forbigående plager, som at vi alle har litt vondt i hodet iblant eller har hatt en vond rygg eller vonde skuldre noen uker. Vi snakker om en markert funksjonssvikt. De som har hatt det lenge og lider av det.

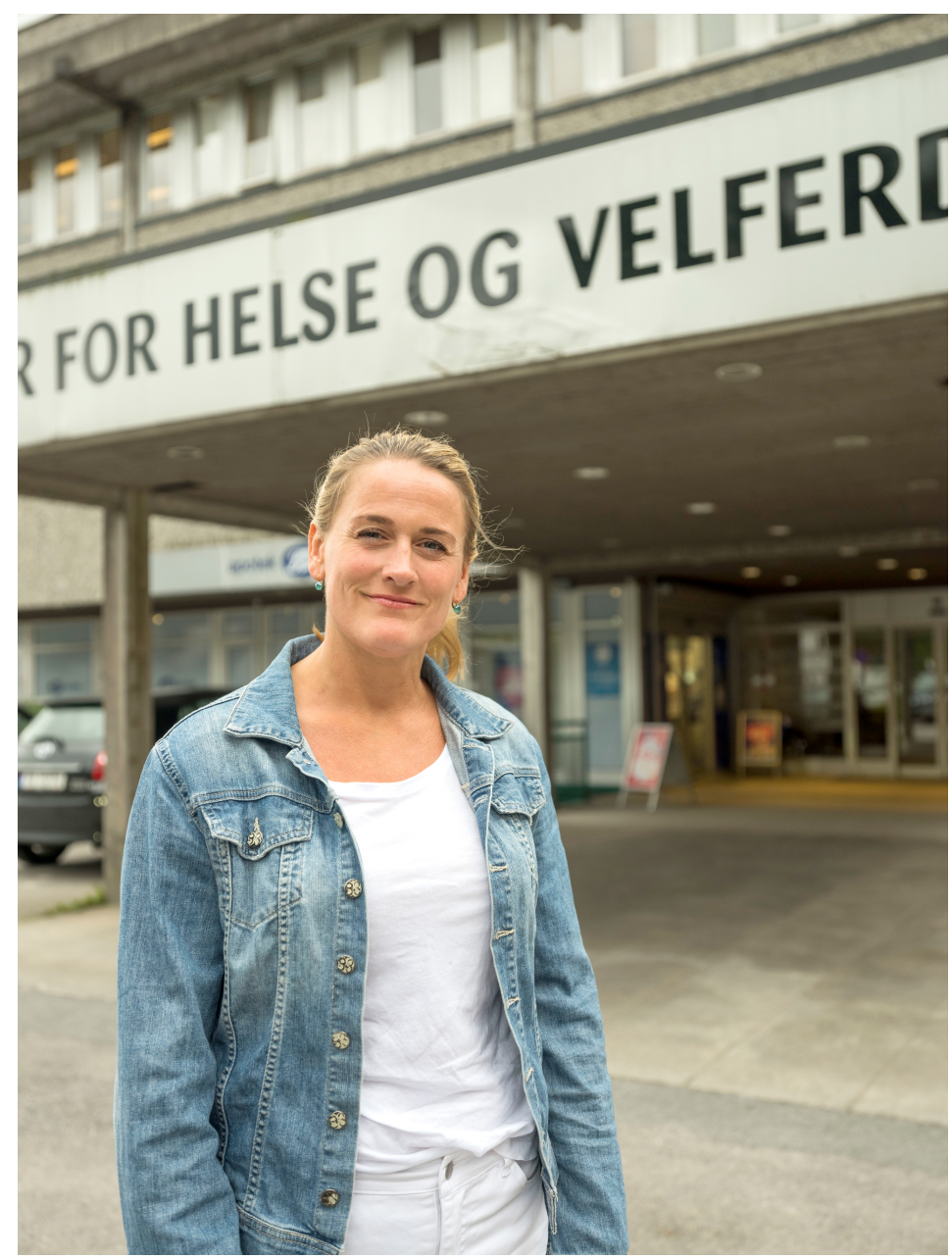

Aase Aamland snakker trygt, rolig og konkret om pasientene som kan gi mange andre grå hår og søvnløse netter. Selv har hun ennå frisk farge i hår og ansikt, og smiler ofte så bredt at øynene smalner mellom teslurkene på bibliotekkafeen i Bergen. Vi sitter i dype stoler under en bugnende grønn vindusplante, med hvite orkideer på bordet. Stemningen har ikke alltid vært like idyllisk i møte med andre kollegers syn på pasientgruppen hun har viet seg til. 


\section{Lite sjokk og mye vantro}

- «Dette er bare tull!», «Vondt i livet!», «Det sitter nok mest mellom ørene!» og lignende har jeg ofte hørt kolleger si. Noen sier rett ut at de ikke tror på det og at de aldri setter denne typen diagnoser. Dette har jeg hatt noen livlige diskusjoner om, sier Aamland oppgitt.

- Hvordan reagerer du på denne typen holdninger?

- Jeg liker jo faglig diskusjoner, men iblant føler jeg meg både frustrert og oppgitt over at flere som jobber midt i dette feltet ikke vil vedkjenne seg at ukjente lidelser finnes. «Blame the victim», det er dessverre sånn det ofte blir når man er usikker selv.

- Men er det ikke en del av dette som faktisk er psykiatri også?

- Noe kan være det, men da er det jo ikke MUPS-tilstander. Jeg har jobbet et år i psykiatrien og møtt flere av disse pasientene der, mange fordi Nav hadde bedt dem om å oppsøke distriktspsykiatriske sentre (DPS). Flere satte seg motvillig ned i stolen og kunne bare si: «Tro meg, det er virkelig ikke noe galt med hodet mitt, jeg har bare veldig vondt i kroppen!».

- Har denne pasientgruppen ekstra lett for å utvikle uhensiktsmessig helseatferd og havne i negative spiraler mellom psyke og soma?

- Jeg skjønner hva du mener, men jeg tenker at det er noe som kjennetegner syke folk generelt, samme om det er MUPS-tilstander, kronisk obstruktiv lungesykdom (kols), hjertesvikt eller depresjon. I alle kategoriene er det pasienter som mestrer sykdommen sin på uhensiktsmessige måter og kommer inn i negative spiraler som gjør at plagene vedlikeholdes. Det er ikke nødvendigvis så spesifikt for MUPS-tilstander. Å være syk gjør noe med deg.

- Godt poeng.

- Takk.

I arbeidet med doktorgraden ville Aase Aamland finne ut hvor godt en del stereotypier om MUPS-pasienter stemte. Det viste seg at det ikke var bare langtidssykmeldte middelaldrende kvinner med lav utdanning. $25 \%$ var menn, $25 \%$ hadde høyere utdanning, og hele $45 \%$ av dem som opplevde langvarig funksjonssvikt, var fortsatt $i$ arbeidsrelatert aktivitet. Hun forteller også ivrig om en ny artikkel hun nettopp fikk publisert i British Journal of General Practice.

- Der har vi samlet suksesshistorier fra allmennleger som har håndtert sine MUPS-pasienter på en effektiv og god måte. Det er mange kolleger der ute som har innarbeidet hjelpsomme strategier, og denne kunnskapen må vi jobbe videre med. Det er mange som gjerne vil lære mer om dette, og det må også inn i medisinerutdanningen, slår hun fast.

\section{Decrescendo}

Men Aamland fordømmer ingen. Særlig ikke de standhaftige fastlegesoldatene som daglig går sine tunge skritt i striden mot venterommet, med hjertet i fritt fall. Hun skjønner frustrasjonen, en følelse som synes å dukke opp overalt i disse dramaene.

- Det er ikke lett. Men en forskningsgruppe i Storbritannia som så på konsultasjoner mellom leger og MUPS-pasienter viste at det oftest var legene selv som ville skrive ut nye medisiner eller initiere videre utredninger. Det er nok en myte vi er med på å skape selv, at pasientene krever så mye hele tiden. Legene krever nok først og fremst veldig mye av seg selv, sier Aamland.

- Men hvor ellers kan disse pasientene få hjelp?

- Vi må ikke tro at vi kan løse alle problemene alene. Helse skapes jo ikke i helsevesenet! Helsen vår skapes jo hver dag ute i samfunnet, der vi lever våre liv.

- Og hva vil det, litt mer konkret, egentlig si?

- Jeg har veldig tro på at deltagelse i samfunnet er viktig, gjennom for eksempel 
frivillighetssentraler og lavterskeltilbud. Selv de som er uføre, har jo ressurser de kan bidra med som det oppleves meningsfylt å bruke. Og så er jeg veldig spent på hvordan man ute i kommunene kan klare å utvikle såkalte primærhelseteam med for eksempel kommunepsykologer, treningsveiledere, kostholdsveiledere og sosionomer.

- Så hva kan egentlig legene bidra med, når de ikke kan behandle?

- Vi må i hvert fall bli flinkere til å sette strek for utredningene og tørre sette en diagnose.

- Men er ikke det igjen et tegn på medikalisering, at alle plager får en medisinsk merkelapp?

- Overdiagnostikk er absolutt en av vår tids største utfordringer, men man må tenke mer på hva som er hensikten med en diagnose. For å stoppe videre utredning og redusere faren for overbehandling er det viktig å kunne si at nok er nok, og kalle det pasientene opplever, ved et navn. Det oppleves ofte meningsfylt for dem. Så kan man rette blikket fremover og jobbe konstruktivt med situasjonen som den er. Slik kan diagnosen i stedet for å være en avslutning på noe, heller bli en begynnelse på noe annet, forklarer Aamland.

Etter at en horde av lunsjende bergensere beleiret kafeen har vi rømt opp trappen til noterommet i bibliotekets musikkavdeling. Der inne i kroken mellom tekster av Jethro Tull og Henning Kvitnes, i ly av hyllen med eldgamle noter for treblåsere, begynner medikaliseringsargumentene å miste sprengkraft. Det føles som jeg kaster dem mot et åpent vann som tar dem villig imot og bare tegner fredelige krusninger på overflaten, før de synker til bunns.

\section{Sørlandsbarn i skogen}

Aamland er ikke til å misforstå når hun etter hvert snakker innstendig om skjevfordelingen mellom forskningen i primær- og spesialisthelsetjenesten. I likhet med mange andre ønsker hun seg etablerte forskningsnettverk av legekontorer som kan bidra til å innhente nyttig kunnskap fra det enorme pasientvolumet i hverdagens Helse-Norge.

- Å kombinere forskning og praksis på den måten jeg har fått gjøre, er en fantastisk mulighet. Etter en kjip dag på jobb med masse tunge skjebner er det herlig å tenke på at man dagen etter skal kunne drikke kaffe og fordype seg i artikler i ro og fred.

- Er det ikke noen andre steder enn i artikler du kan finne fred da?

- Jo, så absolutt! Kall meg gjerne egoistisk, men det viktigste for meg er jo faktisk å ha det godt med meg selv og mine nærmeste. Jeg kommer aldri til å bli en som jobber meg i hjel og ødelegger relasjonene mine, for hva står jeg tilbake med da? Det er ikke pasientene mine jeg skal bli gammel med, sier hun med hevede øyenbryn.

Hun møtte mannen sin under studietiden i Bergen. De fikk sitt første barn det femte året hun studerte, og siden kom to lillesøstre. Nå har eldstemann moped og sommerjobb, mens jentene har kastet seg ut i Kristiansands stupemiljø og må følges på treningsleir i Kroatia. For Aamland selv er det ett sted som gjelder for å finne feriefølelsen, og det er verken i Middelhavet eller på fastlegekontoret.

- Vi har en familiegård i Åmli, så jeg har nok ikke vært like mye på sjøen som andre sørlandsbarn. Vi dro alltid på landet. Der er det låve, stabbur, vognskjul og et gammelt, stort og hvitt våningshus som ligger fint til på en høyde og ser ut over en liten dal.

\section{Ikke mer enn mennesker}

På gården har byfamilien vent seg til å få møkk under neglene uten at de nødvendigvis har stått opp-ned i potetåkeren til alle døgnets tider.

- Men vi er jo hobbybønder som faktisk skal ta over en dag. Så vi arbeider litt, slapper av, går tur og nyter roen. I tillegg har vi bygd låvekino! Bak traktoren har vi en projektor og et stort lerret hvor vi har hatt temakvelder med ungene og sett filmene til Ringenes Herre og James Bond. I sommer så vi Star Wars. Det er veldig hyggelig å være der og gjøre det sammen med 
barna, men selv er jeg nok aller mest glad i å lese bøker.

- Hva slags bøker?

- Vi er fem venninner som har hatt en bokklubb i mange år, og vi leser mye forskjellig som vi diskuterer når vi møtes. Ideen til utekinoen fikk jeg i en bok vi leste av Linn Ullmann, og en av de siste vi har lest, var Du er så lys av Tore Renberg. Den synes jeg var kjempeflott.

Hobbybonde og fastlegeforsker Aamland likte også Svend Brinkmanns bok Stå i mot - si nei til selvutviklingen.

- Den handler vel litt om hvor meningsløst det kan være å bruke livet til å alltid streve etter å være bedre eller gjøre ting bedre. At det beste ikke må bli det godes fiende. Den er ganske vittig, men samtidig litt paradoksal fordi den er enda en bok som forteller oss hvordan vi bør leve.

Hun har selv fått oppleve at livets pensum er vanskelig å forberede, og at eksamener dukker opp helt uanmeldt på kalenderen. Man kan lese seg god på fødselsdepresjon, men det er en hardere øvelse å leve seg god på det.

- Jeg var igjennom det samme med to av mine tre barn, og jeg tuller iblant med at hvis vi skulle hatt en til, hadde jeg endt opp med å bli innlagt.

- Hvordan var det?

- Det er absolutt noe jeg gjerne skulle vært foruten i livet mitt. Det er ikke sånn: «Å, så fantastisk at jeg har hatt det, for da kan jeg bedre forstå andre som har det!». Det virkelig å få kjenne på den psykiske smerten og hvor vond den kan være i forhold til den fysiske, gjør at man blir ganske ydmyk på det at man aldri fullt og helt kan forstå hvordan andre mennesker egentlig har det. Litt erfaring fra den andre siden av gjerdet skader nok ikke, for vi leger kan ofte være dårlige pasienter. Men så er vi ikke mer enn mennesker, vi heller.

Publisert: 16. oktober 2017. Tidsskr Nor Legeforen. DOI:10.4045/tidsskr.17.0652

(C) Tidsskrift for Den norske legeforening 2020. Lastet ned fra tidsskriftet.no 